\title{
Electrochemical Oxidation of Rhodamine B: Optimization and Degradation Mechanism
}

\author{
Qizhou Dai ${ }^{1,2}$, Lei Jiang ${ }^{1}$, Xubiao Luo ${ }^{2, *}$ \\ ${ }^{1}$ College of Environment, Zhejiang University of Technology, Hangzhou 310032, China; \\ ${ }^{2}$ Key Laboratory of Jiangxi Province for Persistent Pollutants Control and Resources Recycle, \\ Nanchang Hangkong University, Nanchang 330063, China \\ *E-mail: luoxubiao@126.com
}

doi: $10.20964 / 2017.05 .60$

Received: 31 January 2017 / Accepted: 24 March 2017 / Published: 12 April 2017

Titanium based lead dioxide electrodes were successfully prepared by the method of electrodeposition in nitrate solution, including titanium base, $\mathrm{Sn}-\mathrm{SbO}$ interlayer, $\alpha-\mathrm{PbO}_{2}$ middle layer and $\beta-\mathrm{PbO}_{2}$ active layer. Rhodamine $\mathrm{B}(\mathrm{RhB})$ was selected as the model pollutant to optimize the effects of operational factors in the electrochemical oxidation process. The removal of $\mathrm{RhB}$ and chemical oxygen demand (COD) were detected at different reaction time and the relative optimized results were achieved on condition of the concentration of supporting electrolyte, initial $\mathrm{RhB}$ concentration, $\mathrm{pH}$ value and applied current density at $0.1 \mathrm{~mol} / \mathrm{L}, 200 \mathrm{mg} / \mathrm{L}, 4.4$, and $20 \mathrm{~mA} / \mathrm{cm}^{2}$, respectively. The kinetics results on $\mathrm{RhB}$ removal indicated that $\mathrm{RhB}$ degradation by electrochemical oxidation followed the pseudofirst-order reaction. Besides, UV-vis spectra revealed that the conjugated structure of RhB was easier and prior to be degraded. The intermediates generated in the solution were identified by GC/MS and a possible degradation pathway of $\mathrm{RhB}$ was proposed.

Keywords: lead dioxide electrode; Rhodamine B; electrochemical oxidation; kinetics

\section{FULL TEXT}

(C) 2017 The Authors. Published by ESG (www.electrochemsci.org). This article is an open access article distributed under the terms and conditions of the Creative Commons Attribution license (http://creativecommons.org/licenses/by/4.0/). 